energetic constraint hypothesis. Animal Behaviour 62:849-861.

LARSON, K. A. 2004. Advertisement call complexity in Northern Leopard Frogs, Rana pipiens. Copeia 2004: 676-682.

Licht, L. E. 1969. Comparative breeding behavior of the Red-Legged Frog (Rana aurora aurora) and the Western Spotted Frog (Rana pretiosa pretiosa) in southwestern British Columbia. Canadian Journal of Zoology 47:1287-1299.

Littlejohn, M. J., Harrison, P. A., and R. C. MacNally. 1985. Interspecific acoustic interactions in sympatric populations of Ranidella signifera and $R$. parinsignifera (Anura: Leptodactylidae). In G. Grigg, R. Shine, and H. Ehrmann (eds.), The Biology of Australasian Frogs and Reptiles, pp. 287-296. Surrey Beatty and Sons. Chipping Norton, New South Wales, Australia.

Murphy, C. G. 1994. Chorus tenure of male Barking Treefrogs, Hyla gratiosa. Animal Behaviour 48:763-777.

Platz, J. E. 1993. Rana subaquavocalis, a remarkable new species of leopard frog (Rana pipiens complex) from Southeastern Arizona that calls under water. Journal of Herpetology 27:154-162.

Pope, C. H. 1944. Amphibians and Reptiles of the Chicago Area. Chicago Natural History Museum. Press, Chicago.

Pough, F. H., M. E., Magnusson, M. J. Ryan, K. D. Wells, and T. L. TAIgeN. 1992. Behavioral energetics. In M. E. Feder and W.W. Burggren (eds.),
Environmental Physiology of the Amphibians, pp. 395-436. Univ. of Chicago Press, Chicago.

Rice, W. R. 1989. Analyzing tables of statistical tests. Evolution 43:223-225.

StebBins, R. C. 1962. Amphibians of Western North America. Univ. of California Press, Berkeley.

Tobias, M. L., C. Barnard, R. O'Hagan, S. H. Horng, M. Rand, AND D. B. Kelly. 2004. Vocal communication between male Xenopus laevis. Animal Behaviour 67:353-365.

WeLLS, K. D. 1977a. The social behaviour of anuran amphibians. Animal Behaviour 25:666-693.

- 1977b. Territoriality and male mating success in the green frog (Rana clamitans). Ecology 58: $750-762$.

. 1978. Territoriality in the green frog (Rana clamitans): vocalizations and agonistic behaviour. Animal Behaviour 26:1051-1063.

Wells, K. D., AND J. J. Schwartz. 1984. Vocal communication in a Neotropical treefrog, Hyla ebraccata: advertisement calls. Animal Behaviour 32:405-420.

White, J. F., AND A. W. White. 2003. Amphibians and Reptiles of Delmarva. Tidewater Publications, Centreville, MD.

YAGER, D. D. 1992. Underwater acoustic communication in the African pipid frog Xenopus borealis. Bioaccoustics 4:1-24.

Accepted: 19 January 2005.

\title{
Revision of the Genus Cnemaspis Strauch, 1887 (Sauria: Gekkonidae), from the Mentawai and Adjacent Archipelagos off Western Sumatra, Indonesia, with the Description of Four New Species
}

\author{
INDRANEIL DAS \\ Institute of Biodiversity and Environmental Conservation, Universiti Malaysia Sarawak, \\ 9300 Kota Samarahan, Sarawak, Malaysia; E-mail: idas@ibec.unimas.my
}

\begin{abstract}
Aвstract.-Four new species of Cnemaspis are described from the Mentawai and adjacent archipelagos along the northwest to the southwest coast of Sumatra, Republic of Indonesia, and one each from Simeulue, Nias, Siberut, and Enggano. These populations were allocated by earlier workers to Cnemaspis kandiana (Kelaart, 1852), a Sri Lankan highland endemic. The high levels of endemicity of the fauna of these islands have been attributed to their geographical isolation, historical lack of aridity, and effects of glacial emergence of the Sunda Shelf caused by its maritime climate.
\end{abstract}

The Mentawai Archipelago (Kepulauan Mentawai in Bahasa Indonesia), comprising Siberut, Tanahbala, Sipura (Sipora in the older literature), Pagai Utara, and Pagai Selatan, and adjacent islands (including the Simeulue of the Banyak Archipelago, and the Nias and Enggano groups), stretch approximately $1100 \mathrm{~km}$ along the northwest to the southwest coast of Sumatra. They are 
arguably the most ecologically unique of the tropical archipelago systems of the world. At the narrowest point, $120 \mathrm{~km}$ southwest of Sumatra, in the Greater Sundas, Republic of Indonesia, these archipelagos support a high primate diversity, with as many as eight species of apes and monkeys occurring in sympatry, of which four are endemic to these islands (McNeely and Wachtel, 1988; Whitten et al., 2000; Roos et al., 2003). The high endemicity is thought to be caused by the deep straits separating many of these islands from Sumatra, ensuring their isolation during the the Pleistocene, when sea levels fell by as much as $120 \mathrm{~m}$ below present levels (Bloom, 1983: Chappell and Thom, 1977; Voris, 2000).

Herpetological investigations of the Mentawai and adjacent island groups have a relatively long history (for example, see Boulenger, 1885, 1890; Modigliani, 1889; van Lidth de Jeude, 1890; Vinciguerra, 1892; Werner, 1892; De Rooij, 1915a; Roux, 1925; Kopstein, 1937; reviewed by Smith, 1926). A species of Cnemaspis has been known from these islands for over a century: Boulenger (1890) referred it to Gonatodes kandiana (Kelaart, 1852) as did De Rooij (1915b, 1922). Brongersma (1934) and Dring et al. (1990) referred to these populations as C. kandiana, a species described originally from the central highlands of Sri Lanka, and also reported from mainland India (Annandale, 1909; Abdulali, 1955; Thakur, 1998; Thomas and Easa, 1997), the Andaman and Nicobar Islands (Smith, 1935), and southern Thailand (Taylor, 1963; Cox et al., 1998) and Sumatra (De Rooij, 1915b; Rösler, 1981). Bauer (2002) argued that the Western Ghats populations belong to species distinct from C. kandiana, and Das and Leong (2004) recognised the southern Thai population as a distinct species.

The purpose of this paper is to evaluate the systematic status of Cnemaspis from the islands of Mentawai and adjacent islands. In doing so, four new species represented by museum specimens were found and are described herein.

\section{Materials AND Methods}

All specimens examined are listed in Appendix 1. The following measurements were taken with Mitutoyo $^{\mathrm{TM}}$ dial caliper (to the nearest $0.1 \mathrm{~mm}$ ): snout-vent length (SVL; from tip of snout to vent), tail length (TL; from vent to tip of unregenerated tail), tail width (TW; measured at base of tail); head length (HL; distance between posterior edge of last supralabial and snout-tip), head width (HW; measured at angle of jaws), head depth (HD; maximum height of head, from occiput to throat), ear length (EL; greater ear length); forearm length (FA; distance between the palm and elbow); eye diameter (ED; greatest diameter of orbit), eye to nostril distance (E-N; distance between anteriormost point of eyes and nostrils), eye to snout distance (E-S; distance between anteriormost point of eyes and tip of snout), eye to ear distance (E-E; distance from anterior edge of ear opening to posterior corner of eyes), internarial distance (IN; distance between nares), interorbital distance (IO; shortest distance between orbits) and and tibia length (TBL; length of tibia). Scale counts and external observations of morphology were made using an Olympus SZX9 dissecting microscope. Radiographic examination was done at $40 \mathrm{Kv}(2 \mathrm{~mA})$ for $30 \mathrm{sec}$. Sexes were determined on the basis of the presence of hemipeneal swellings, complimented in some species with the presence of preanal and femoral pores, indicative of males. Additional sources of information on character states include De Rooij (1915b), Smith (1935), Dring (1979), Das (1993), Manthey and Grossmann (1997), Das and Bauer (1998); Bauer and Das (1998), and Das and Grismer (2003). Institutional abbreviations follow Leviton et al. (1985). Geographical coordinates were extracted from gazetteers for Indonesia, produced by the Defense Mapping Agency, U.S. Board of Geographic Names, Washington, DC, also accessible through http://164.214.2.59/gns/html/.

\section{SYSTEMATICS}

Cnemaspis dezwaani sp. nov. Figure 1

Holotype.-ZMA 11988.1, Lelewua (spelt Lelenaea in the past, $01^{\circ} 13^{\prime} \mathrm{N} ; 97^{\circ} 34^{\prime} \mathrm{E}$; altitude $360 \mathrm{~m}$ ASL), Sumatera Utara Propinsi, Republic of Indonesia (Fig. 5); adult male, collector: Johannes Pieter Kleiweg de Zwaan; sampling details unavailable, except that de Zwaan visited Nias in 1910 (see Fransen et al., 1997:252).

Paratype.-ZMA 11988.2, paratopotype; adult male, other data as for holotype.

Diagnosis.-A small species of Cnemaspis (SVL to $31.4 \mathrm{~mm}$ ), diagnosable from conspecifics in showing the following combination of characters: two semicircular supranasals that are separated by a single scale; three postnasals bound nasal; four scale rows separate orbit from supralabials; posteriorly, each postmental is bounded by three smooth, rounded and juxtaposed scales; scattered spinose paravertebral rows of tubercles on dorsum; pectoral and abdominal scales not elongated, imbricate, bearing a single keel; tail segmented, with enlarged flattened scales forming whorls, a single spinose postcloacal spur present; median subcaudals enlarged, unicarinate; supralabials (to midorbit position) 6; infralabials 7; lamellae under toe IV 18-19; adult males with 4-6 pairs of preanal pores and 3 femoral pores. 